\title{
Penerapan Algoritma Random Forest dengan Kombinasi Ekstraksi Fitur Untuk Klasifikasi Penyakit Daun Tomat
}

\author{
Umi Khultsum ${ }^{1, *}$, Agus Subektii,2 \\ ${ }^{1}$ Ilmu Komputer, STMIK Nusa Mandiri, Jakarta, Indonesia \\ ${ }^{2}$ Lembaga Ilmu Pengetahuan Indonesia, Indonesia \\ Email: 1,"*14002375@nusamandiri.ac.id, ${ }^{2}$ agus@ @usamandiri.ac.id, ${ }^{2}$ agus.subekti@lipi.go.id \\ Email Penulis Korespondensi: 14002375@ nusamandiri.ac.id
}

\begin{abstract}
Abstrak-Tanaman tomat banyak dikonsumsi oleh masyarakat dan banyak dibudidayakan oleh petani. Tanaman tomat rentan terhadap serangan penyakit. Penyakit pada tanaman menyebabkan penurunan kualitas serta kuantitas tanaman atau hasil pertanian. Ide revolusi pertanian 4.0 muncul sebagai dampak dari revolusi industri 4.0. Para petani belum siap menghadapi kemajuan teknologi yang semakin pesat. Penting dalam mengidentifikasi penyakit pada daun tomat secara benar dalam efisiensi manajemen penyakit untuk upaya pengendalian agar penyakit pada daun tomat tidak berkembang. Tujuan utama dari metode yang diusulkan adalah mengembangkan teknik untuk mengidentifikasi penyakit daun pada tanaman tomat dengan meningkatkan akurasi klasifikasi. Kebaruan dari penelitian ini adalah kombinasi beberapa ekstraksi fitur untuk meningkatkan akurasi klasifikasi. Fitur yang digunakan yaitu fitur warna, fitur Hu-Moment, dan firur haralick. Dalam proses klasifikasi menerapkan algoritma Random Forest dan algoritma klasifikasi lainya sebagai perbandingan. Pada penelitian ini metode Random Forest dan kombinasi fitur esktraksi berhasil menunjukkan peningkatan akurasi, akurasi yang diperoleh yaitu $96 \%$.
\end{abstract}

Kata Kunci: Penyakit Tanaman Tomat; Klasifikasi; Fitur Warna; Fitur Hu-Moment; Fitur Haralick

\begin{abstract}
The tomato plant is widely consumed by the community and is widely cultivated by farmers. Tomato plants are susceptible to disease attacks. Plant diseases cause a decrease in the quality and quantity of crops or agricultural produce. The idea of the 4.0 agricultural revolution emerged as a result of the 4.0 industrial revolution. Farmers are not ready to face increasingly rapid technological advances. It is important to identify the disease in tomato leaves correctly in the efficiency of disease management for efforts to control so that disease in tomato leaves does not develop. The main objective of the proposed method is to develop a technique for identifying foliar diseases in tomato plants by increasing the classification accuracy. The novelty of this research is a combination of several feature extractions to improve classification accuracy. The features used are the color feature, the Hu-Moment feature, and the firur haralick. In the classification process, the Random Forest algorithm and other classification algorithms are applied for comparison. In this study, the Random Forest method and the combination of extraction features have shown an increase in accuracy, the accuracy obtained is $96 \%$.
\end{abstract}

Keywords: Tomato Plant Diseases; Classification; Color Features; Hu-Moment Features; Haralick Features

\section{PENDAHULUAN}

Pertanian menjadi tulang punggung untuk kehidupan masyarakat, selain itu memiliki dampak yang besar bagi perekonomian bangsa. Tanaman tomat merupakan tanaman sayuran yang terkenal dan banyak dikonsumsi oleh masyarakat di berbagai negara. Saat ini tanaman tomat merupakan komoditas sayuran yang mengalami peningkatan dari tahun ke tahun. Tanaman tomat banyak dibudidayakan oleh petani, baik pada dataran rendah maupun dataran tinggi dan dapat tumbuh hampir di berbagai negara [1].

Tanaman tomat rentan terhadap serangan penyakit. Penyakit yang menyerang tanaman tomat dapat disebabkan oleh jamur atau cendawan, bakteri dan virus yang menyarang pada bagian daun. Penyakit ini dapat dikenali secara visual karena memiliki ciri tekstur dan warna yang unik. Pengenalan yang dilakukan secara visual oleh petani memiliki kekurangan yaitu membutuhkan waktu yang lama dan dalam mengidentifikasi penentuan jenis penyakit ini tidak akurat karena terdapat kemiripan antara satu jenis penyakit dengan penyakit lainya [2].

Ide revolusi pertanian 4.0 muncul sebagai dampak dari revolusi industri 4.0. Pertanian 4.0 dicirikan menghasilkan benih unggul berbasis bioinformatika, pengendalian hama terintegrasi yang cerdas dengan kecerdasan buatan, pemupukan presisi, penggunaan traktor pintar, penyemaian benih dengan robot dan pabrik pabrik, non-pertanian yang tidak hanya berbicara tentang agroindustri cerdas tetapi juga sistem logistik pertanian digital [3]. Teknologi ini mendukung konsep seperti pertanian vertikal dan sistem pangan, pertanian digital, bioekonomi, pertanian melingkar, dan aquaponik. Namun permasalahan muncul ketika para petani belum siap menghadapi kemajuan teknologi yang semakin pesat [4].

Saat ini teknologi yang semakin berkembang, salah satunya dalam bidang pengolahan citra. Melelui pengenalan pola atau karakteristik dari citra daun yang terkena penyakit tersebut, diharapkan dapat menjadi langkah yang penting dalam mengidentifikasi penyakit secara benar dalam efisiensi manajemen penyakit, sehingga dapat dilakukan upaya pengendalian agar penyakit pada daun tomat tidak berkembang atau menyebar. Dalam hal ini algoritma klasifikasi dan berbagai ekstraksi fitur diterapkan untuk deteksi penyakit pada daun tomat.

H. Sabrol dan S. Kumar [5], melakukan penelitian menggunakan algoritma klasifikasi dan ekstraksi fitur. Penelitian tersebut menerapkan algoritma Decision Tree dan fitur warna dalam klasifikasi penyakit daun tomat. Akurasi yang dihasilkan dengan algoritma decision tree yaitu $78 \%$.

Hang, dkk [6], mengusulkan metode berbasis pembelajaran mendalam untuk mengidentifikasi dan mengklasifikasikan penyakit daun tanaman. Metode yang diusulkan mengambil keuntungan dari neural network 
untuk mengekstraksi karakteristik bagian yang terserang penyakit, dan dengan demikian mengklasifikasikan sasaran area penyakit. Model yang diusulkan menghasilkan kinerja yang lebih baik dan mencapai akurasi $91,7 \%$ pada kumpulan data uji.

Vamsidhar dkk [7], mengembangkan teknik segmentasi untuk deteksi otomatis dan klasifikasi pada penyakit tanaman. Fitur ekstraksi yang dipilih digunakan untuk pelatihan pada Algoritma klasifikasi Support Mesin Vektor (SVM) dan Artificial Neural Network (ANN). Fitur tekstur dan warna diekstraksi untuk mendapatkan set fitur yang lebih baik sebagai masukan untuk algoritma klasifikasi. K-means juga digunakan sebagai klasifikasi dan diketahui bahwa akurasi yang dihasilkan 85,3\%. SVM yang digunakan untuk klasifikasi pada penelitian ini diperoleh akurasi sebesar 90\%. Linear Kernel diterapkan dalam SVM dan menghasilkan akurasi klasifikasi 89\%. Kernel RBF menghasilkan akurasi 88,8\% dan kernel polinomial 90,2\%. Metode Naive Bayes memperoleh akurasi sebesar $86 \%$.

Owomugisha dkk [8], memperkenalkan teknik di mana fitur histogram warna diekstraksi dan mengubah ruang warna dari model warna RGB ke HSV, model warna RGB ke L * a * b. Algoritma klasifikasi yang berbeda seperti Random Forest, SVM, Nearest Neighbours, Naïve Bayes, Decision Tree, Extremely Randomized Tree digunakan. Dari jumlah tersebut, Extremely Randomized Tree terbukti lebih efisien daripada pengklasifikasi lainnya.

Rothe dan Kshirsagar [9], mengusulkan metode menggunakan snake segmentation approach. Momen Hu digunakan sebagai fitur pembeda. Model kontur aktif digunakan untuk meminimalkan vitalitas di daerah yang terinfeksi. Back Propagation Neural Network (BPNN) digunakan untuk mengklasifikasikan penyakit daun. Akurasi klasifikasi rata-rata adalah $85,52 \%$.

Jagadeesh dan Audre [10], melakukan penelitian klasifikasi pada penyakit daun tomat dengan menggunakan metode Random Forest dan Decision Tree. Sebelum melakukan klasifikasi, mereka memoroses citra dengan ekstraksi fitur Color histograms, Hu Moments, Haralick dan Local Binary Pattern. Dalam penelitiannya menggunakan 4 kelas penyakit daun tomat. Berdasarkan percobaan yang dilakukan, didapatkan bahwa Random Forest lebih akurat daripada Decision Tree. Akurasi klasifikasi masing-masing adalah $90 \%$ untuk pengklasifikasi Decision Tree dan 94\% untuk pengklasifikasi Random Forest.

Pada penlitian ini, diusulkan Algoritma Random Forest dengan kombinasi 3 ekstraksi fitur yaitu fitur warna, fitur Hu-Moment, dan fitur haralick pada citra penyakit daun tomat dengan menggunakan 10 kelas penyakit. Pada penelitian yang diusulkan ini hasil akurasi mengalami peningkatan dibandingkan dengan penelitain sebelumnya yang telah dipaparkan diatas. Selanjutnya pada paper ini kami memaparkan metode penelitian pada bagian 2, hasil dan pembahasan pada bagian 3, dan pada bagian 4 memaparkan kesimpulan dari penelitian ini.

\section{METODOLOGI PENELITIAN}

Pada bagian ini menjelaskan metode penelitian yang diterapkan dalam penelitian ini. Eksperimen pada penelitian ini dilakukan dengan menggunakan sklearn [11], opencv [12], dan mahotas [13]. Dataset yang digunakan yaitu citra penyakit daun tomat yang diambil dari https://www.kaggle.com/kaustubhb999/tomatoleaf. Kemudian dataset tersebut diekstraksi menggunakan gubungan 3 fitur, yaitu fitur warna, fitur Hu-Moment, dan fitur Haralick. Setelah selesai dilakukan ekstraksi fitur kemudian dilakukan proses klasifikasi. Berikut alur metode penelitian dapat dilihat pada Gambar 1.

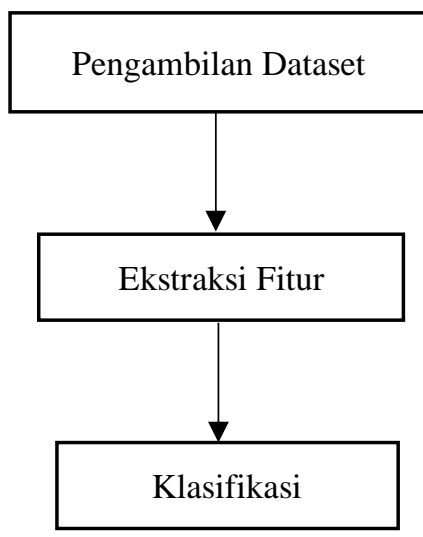

Gambar 1. Alur Metode Penelitian

\subsection{Pengambilan Dataset}

Dataset penyakit daun tomat diambil dari Kaggle dengan jumlah 10.000 data. Dataset tersebut terdapat 10 kelas, yaitu:

a. Kelas Bacterial Spot

Terdapat 1.000 citra pada kelas ini dengan dimensi 256x256 
JURNAL MEDIA INFORMATIKA BUDIDARMA

Volume 5, Nomor 1, Januari 2021, Page 186-193

ISSN 2614-5278 (media cetak), ISSN 2548-8368 (media online)

Available Online at https://ejurnal.stmik-budidarma.ac.id/index.php/mib DOI 10.30865/mib.v5i1.2624

b. Kelas Early Blight

Terdapat 1.000 citra pada kelas ini dengan dimensi 256x256

c. Kelas Healthy

Terdapat 1.000 citra pada kelas ini dengan dimensi 256x256

d. Kelas Late Blight

Terdapat 1.000 citra pada kelas ini dengan dimensi 256x256

e. Kelas Leaf Mold

Terdapat 1.000 citra pada kelas ini dengan dimensi 256x256

f. Kelas Septoria Leaf Spot

Terdapat 1.000 citra pada kelas ini dengan dimensi 256x256

g. Kelas Spider Mites

Terdapat 1.000 citra pada kelas ini dengan dimensi 256x256

h. Kelas Target Spot

Terdapat 1.000 citra pada kelas ini dengan dimensi 256x256

i. Kelas Mosaic Virus

Terdapat 1.000 citra pada kelas ini dengan dimensi 256x256

j. Kelas Yellow Leaf Curl Virus

Terdapat 1.000 citra pada kelas ini dengan dimensi 256x256

Tabel 1. Sampel Citra

\begin{tabular}{|c|c|c|c|}
\hline Kelas & Sampel Citra & Kelas & Sampel Citra \\
\hline Bacterial Spot & & $\begin{array}{c}\text { Septoria Leaf } \\
\text { Spot }\end{array}$ & \\
\hline Early Blight & & Spider Mites & \\
\hline Healthy & & Target Spot & \\
\hline Late Blight & & Mosaic Virus & \\
\hline Leaf Mold & & Yellow Leaf & \\
\hline
\end{tabular}

\subsection{Ekstraksi Fitur}

Dalam ekstraksi fitur pada penelitian ini menggunakan 3 fitur, yaitu:

a. Fitur Warna

Fitur Histogram Warna menangkap informasi warna dari suatu citra, termasuk distribusi warna citra, kontras citra, dan distribusi kecerahan piksel. Fitur Histogram Warna menjelaskan citra berdasarkan histogram hasil 
indeks Vector Quantization (VQ). Citra berwarna pertama-tama dibagi menjadi beberapa blok citra. Warna yang diindeks VQ dapat dihitung dari dua penghitung citra, yaitu penghitung min dan maksimum, dari setiap blok citra. Kedua pembilang dapat secara memadai mewakili blok citra berwarna seperti yang sebelumnya digunakan dalam pengkodean pemotongan blok halftoningbased [14].

Histogram warna dalam sebuah citra menggambarkan penyebaran warna. Dalam pengolahan citra, histogram warna melambangkan banyaknya kemunculan suatu warna tertentu. Histogram warna dapat dibuat di ruang warna apa saja. Umumnya, ruang warna dipisahkan menjadi sejumlah rentang yang sesuai, masingmasing terdiri dari nilai warna yang sama. Dapat dicontohkan sebagai fungsi halus yang ditentukan pada ruang warna tertentu yang memperkirakan jumlah piksel [10]. Histogram warna daun tomat yang terserang penyakit ditunjukkan pada Gambar 2.
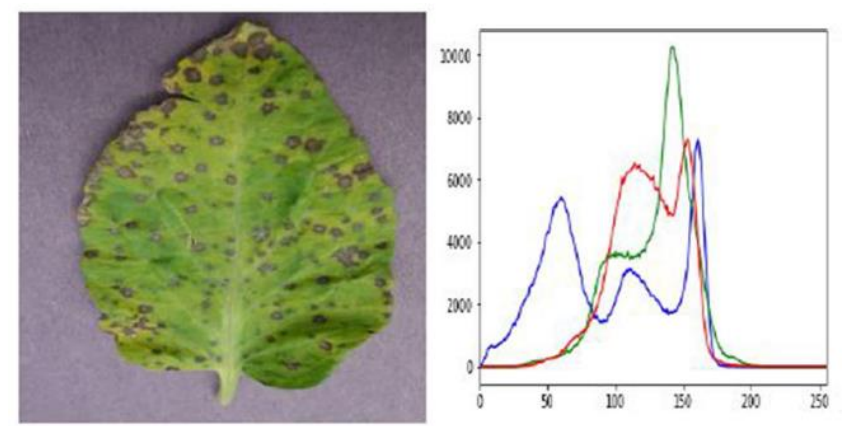

b. Fitur Haralick

Gambar 2. Histogram Warna

Tekstur merupakan salah satu elemen penting dalam persepsi visual manusia. Pendekatan tekstur statistik mempertimbangkan distribusi nilai abu-abu dalam domain spasial dengan menemukan fitur lokal setiap piksel pada citra yang diberikan dan menyimpulkan sekumpulan parameter statistik menggunakan distribusi fitur local [10].

Fitur Haralick berisi data tentang karakteristik tekstur citra, misalnya, homogenitas, dependensi linier warna abu-abu, kontras, jumlah dan sifat batas yang ada, bersama dengan indeks kompleksitas yang melekat pada citra [15].

c. Fitur Hu-Moment

Fitur selanjutnya yaitu fitur bentuk, ekstraksi momen hu. Pada dasarnya, momen citra didefinisikan sebagai rata-rata bobot dari intensitas piksel citra. Citra momen $\mathrm{M}_{\mathrm{ij}}$ untuk citra $\mathrm{I}(\mathrm{x}, \mathrm{y})$ diberikan oleh jumlah intensitas piksel, dinyatakan sebagai

$M_{i j}=\sum_{i} \sum_{j} I(x, y)$

Dalam Persamaan. (1), penjumlahan intensitas piksel dihitung. Dengan kata lain, intensitas piksel dibobotkan berdasarkan intensitasnya dan tidak bergantung pada lokasinya. Untuk citra biner, momen dianggap sebagai jumlah piksel putih atau wilayah putih pada citra. Agar dua bentuk menjadi serupa, momen citra pada dasarnya akan sama, tetapi itu bukan bentuk yang memadai. Dua citra dengan momen yang sama dapat dikonstruksi meskipun citra tersebut tampak berbeda. Karenanya ada kebutuhan untuk menemukan momen stabil. Momen sentral sangat identik dengan momen citra mentah yang memiliki persamaan sebagai berikut

$\mu_{i j}=\sum_{x} \sum_{y}(x-\bar{x})^{i}(y-\bar{y})^{j} I(x, y)$

Momen sentral tidak berubah dari skala, terjemahan, dan rotasi. Ini akan cukup untuk kondisi pencocokan bentuk. Momen adalah sekelompok tujuh angka yang ditentukan menggunakan momen pusat yang tidak berubah dari transformasi citra. Enam momen pertama terbukti tidak berubah dari skala, terjemahan, refleksi, dan rotasi. Tanda momen ketujuh akan berubah seiring dengan pantulan bayangan.

Fitur momen Hu sering digunakan sebagai parameter deskripsi fitur citra. Setelah posisi dan ukuran objek citra diperoleh momen asal dan momen sentral, maka dihitung fitur momen Hu untuk menilai apakah koordinat citra berubah. Berdasarkan teori invarian momen wilayah, dibangun fitur tujuh momen dengan invarian translasi, rotasi, penskalaan, dan skala, yang dapat menggambarkan bentuk wilayah ruang [16]. Persamaan untuk tujuh momen adalah sebagai berikut:

$h_{0}=\eta_{20}+\eta_{02}$

$h_{1}=\left(\eta_{20}-\eta_{02}\right)^{2}+4 \eta_{11}^{2}$ 
ISSN 2614-5278 (media cetak), ISSN 2548-8368 (media online)

Available Online at https://ejurnal.stmik-budidarma.ac.id/index.php/mib DOI 10.30865/mib.v5i1.2624

$$
\begin{aligned}
& h_{2}=\left(\eta_{30}-3 \eta_{12}\right)^{2}+\left(3 \eta_{21}-\eta_{03}\right)^{2} \\
& h_{3}=\left(\eta_{30}-\eta_{12}\right)^{2}+\left(\eta_{21}-\eta_{03}\right)^{2} \\
& h_{4}=\left(\eta_{30}-3 \eta_{12}\right)\left(\eta_{30}+\eta_{12}\right)\left[\left(\eta_{30}+\eta_{12}\right)^{2}-3\left(\eta_{21}+\eta_{03}\right)^{2}\right]+\left(3 \eta_{21}+\eta_{03}\right)\left[3\left(\eta_{30}+\eta_{12}\right)^{2}\right. \\
& \left.+\left(\eta_{21}+\eta_{03}\right)^{2}\right] \\
& h_{5}=\left(3 \eta_{21}-\eta_{03}\right)\left[\left(\eta_{30}+\eta_{12}\right)^{2}-\left(\eta_{21}+\eta_{03}\right)^{2}\right] 4 \eta_{11}\left(\eta_{30}+\eta_{12}\right)\left(\eta_{21}+\eta_{03}\right) \\
& h_{6}=\left(3 \eta_{21}-\eta_{03}\right)\left(\eta_{30}+\eta_{12}\right)\left[\left(\eta_{30}+\eta_{12}\right)^{2}-3\left(\eta_{21}+\eta_{03}\right)^{2}\right. \\
& +\left(\eta_{30}+3 \eta_{12}\right)\left(\eta_{21}+\eta_{03}\right)\left[3\left(\eta_{30}+\eta_{12}\right)^{2}-\left(\eta_{21}+\eta_{03}\right)^{2}\right]
\end{aligned}
$$

\subsection{Random Forest}

Random Forest adalah metodologi pelatihan gabungan untuk regresi, klasifikasi, dll. Random Forest terdiri dari beberapa pohon keputusan. Random Forest meringkas hasil dari semua pohon keputusan pada waktu pelatihan dan mengeluarkan kelas jika terjadi masalah klasifikasi dan prediksi rata-rata jika modelnya regresi. Algoritma ini mengatasi masalah overfitting ke set pelatihan mereka, yang merupakan masalah utama dalam pohon keputusan algoritma [17].

Random Forest (RF) adalah kumpulan hierarki pengklasifikasi dasar terstruktur pohon. Data biasanya memiliki banyak dimensi. Dataset berisi sejumlah besar atribut yang tidak relevan. Hanya sedikit atribut penting yang informatif untuk model classifer. Algoritma RF menggunakan probabilitas sederhana yang telah ditentukan sebelumnya untuk memilih atribut relevan yang paling penting. Breiman merumuskan algoritma RF menggunakan subset data sampel dan untuk membangun beberapa pohon keputusan dengan memetakan sampel acak dari subr uang fitur [18]. Tahapan pada algoritma Random Forest sebagai berikut [19]:

a. Tentukan jumlah tree (k) yang akan dibentuk, jumlah $\mathrm{k}$ dipilih dari total fitur $\mathrm{m}$, di mana k kurang dari $\mathrm{m}$.

b. Sampel acak diambil sebanyak N observasi (with replacement) pada dataset untuk setiap tree.

c. Pada setiap tree, dilakukan juga pengambilan subset prediktor sebanyak secara acak. Dimana $\mathrm{m}<\mathrm{p}, \mathrm{p}$ adalah jumlah variabel prediktor

d. Proses kedua dan ketiga diulangi sampai sebanyak $\mathrm{k}$ tree.

e. Pada kasus klasifikasi, hasil prediksi Random Forest diperoleh dari vote terbanyak (majority vote) dari hasil klasifikasi sebanyak tree.

\section{HASIL DAN PEMBAHASAN}

\begin{tabular}{|c|c|c|c|c|c|}
\hline Kelas & Fitur Haralick & Fitur Warna & Kelas & Fitur Haralick & Fitur Warna \\
\hline $\begin{array}{l}\text { Bacterial } \\
\text { Spot }\end{array}$ & & & $\begin{array}{l}\text { Septoria } \\
\text { Leaf Spot }\end{array}$ & & \\
\hline Early Blight & & & $\begin{array}{l}\text { Spider } \\
\text { Mites }\end{array}$ & & \\
\hline Healthy & & & $\begin{array}{l}\text { Target } \\
\text { Spot }\end{array}$ & & \\
\hline Late Blight & & & Mosaic & & \\
\hline
\end{tabular}

Berdasarkan metode penelitian yang telah diuraikan sebelumnya, pengujian dataset penyakit pada daun tomat dilakukan dengan metode klasifikasi. Kemudian untuk mengetahui fitur mana yang digunakan dalam penelitian ini yang mempunyai performa paling baik maka dilakukan percobaan variasi fitur, yaitu fitur Hu-Moments, fitur Haralick, dan fitur warna. Hasil yang didapatkan pada proses ekstraksi fitur Haralick dan Fitur Warna ditampilkan pada tabel 2.

Tabel 2. Hasil Ekstraksi Fitur Haralick dan Fitur Warna 
JURNAL MEDIA INFORMATIKA BUDIDARMA

Volume 5, Nomor 1, Januari 2021, Page 186-193

ISSN 2614-5278 (media cetak), ISSN 2548-8368 (media online)

Available Online at https://ejurnal.stmik-budidarma.ac.id/index.php/mib

DOI 10.30865/mib.v5i1.2624

\begin{tabular}{|c|c|c|c|c|c|}
\hline Kelas & Fitur Haralick & Fitur Warna & Kelas & Fitur Haralick & Fitur Warna \\
\hline Leaf Mold & & & $\begin{array}{l}\text { Yellow } \\
\text { Leaf Curl } \\
\text { Virus }\end{array}$ & & \\
\hline
\end{tabular}

Dari tabel diatas terlihat perbedaan warna pada hasil ekstraksi dari citra pada masing-masing kelas penyakit daun tomat. Setelah itu dilakukan proses ekstraksi fitur Hu-Moment. Berikut hasil dari proses fitur Hu-Moment dapat dilihat pada tabel 3.

Tabel 3. Hasil Fitur Hu-Moment

\begin{tabular}{llccllll}
\hline \multicolumn{1}{c}{ Kelas } & \multicolumn{1}{c}{$\boldsymbol{h}_{\mathbf{0}}$} & \multicolumn{1}{c}{$\boldsymbol{h}_{\mathbf{1}}$} & \multicolumn{1}{c}{$\boldsymbol{h}_{\mathbf{2}}$} & \multicolumn{1}{c}{$\boldsymbol{h}_{\mathbf{3}}$} & \multicolumn{1}{c}{$\boldsymbol{h}_{\mathbf{4}}$} & \multicolumn{1}{c}{$\boldsymbol{h}_{\mathbf{5}}$} & \multicolumn{1}{c}{$\boldsymbol{h}_{\mathbf{6}}$} \\
\hline Bacterial & 1.867306 & 5.23003 & 1.7960 & 2.31415 & 3.0213819 & -3.79336019 & $3.62446883 \mathrm{e}-$ \\
Spot & $68 \mathrm{e}-03$ & $808 \mathrm{e}-10$ & $567 \mathrm{e}-11$ & $998 \mathrm{e}-11$ & $4 \mathrm{e}-22$ & $\mathrm{e}-17$ & 22 \\
Early Blight & 1.599183 & 6.43170 & 1.50078 & 2.41400 & 2.2623122 & -1.16557986 & $3.99927439 \mathrm{e}-$ \\
& $05 \mathrm{e}-03$ & $631 \mathrm{e}-09$ & $994 \mathrm{e}-11$ & $530 \mathrm{e}-11$ & $2 \mathrm{e}-22$ & $\mathrm{e}-15$ & 22 \\
Healthy & 2.102475 & 2.08348 & 6.29538 & 1.34892 & 3.8603715 & -1.63198229 & $7.41365312 \mathrm{e}-$ \\
& $30 \mathrm{e}-03$ & $387 \mathrm{e}-10$ & $130 \mathrm{e}-11$ & $688 \mathrm{e}-11$ & $9 \mathrm{e}-22$ & $\mathrm{e}-16$ & 23 \\
Late Blight & 1.356613 & 1.75871 & 1.89063 & 9.62089 & 3.1528484 & 7.54940298 & $-2.62604284 \mathrm{e}-$ \\
& $30 \mathrm{e}-03$ & $626 \mathrm{e}-08$ & $072 \mathrm{e}-11$ & $561 \mathrm{e}-11$ & $6 \mathrm{e}-21$ & $\mathrm{e}-15$ & 21 \\
Leaf Mold & 1.666114 & 6.24990 & 5.55360 & 3.06071 & 1.2226606 & -2.12306521 & $3.12211364 \mathrm{e}-$ \\
Septoria & $24 \mathrm{e}-03$ & $982 \mathrm{e}-09$ & $237 \mathrm{e}-11$ & $944 \mathrm{e}-11$ & $5 \mathrm{e}-21$ & $\mathrm{e}-15$ & 22 \\
Leaf Spot & 1.323909 & 4.58158 & 6.76716 & 3.40262 & 2.7575705 & 5.79731946 & $-1.60931464 \mathrm{e}-$ \\
Spider & $05 \mathrm{e}-03$ & $698 \mathrm{e}-10$ & $899 \mathrm{e}-13$ & $594 \mathrm{e}-13$ & $9 \mathrm{e}-26$ & $\mathrm{e}-18$ & 25 \\
Mites & 1.363009 & 2.46978 & 5.03624 & 2.27383 & 6.3928882 & 9.52376881 & $2.34779322 \mathrm{e}-$ \\
Target Spot & 1.498602 & $612 \mathrm{e}-09$ & $326 \mathrm{e}-12$ & $248 \mathrm{e}-11$ & $5 \mathrm{e}-23$ & $\mathrm{e}-16$ & 22 \\
Mosaic & $20 \mathrm{e}-03$ & $269 \mathrm{e}-09$ & $474 \mathrm{e}-11$ & $006 \mathrm{e}-12$ & $6 \mathrm{e}-23$ & $\mathrm{e}-16$ & 24 \\
Virus & 1.402023 & 4.00276 & 7.78639 & 6.75471 & 1.3911861 & 9.83476073 & $-6.81396270 \mathrm{e}-$ \\
Yellow Leaf & $1.86 \mathrm{e}-03$ & $949 \mathrm{e}-10$ & $941 \mathrm{e}-13$ & $067 \mathrm{e}-12$ & $9 \mathrm{e}-23$ & $\mathrm{e}-17$ & 24 \\
Curl Virus & $12 \mathrm{e}-03$ & 4.47878 & 4.61800 & 2.26006 & 7.2057899 & 4.74538539 & $1.17803471 \mathrm{e}-$ \\
\hline
\end{tabular}

Setelah mengetahui hasil dari percobaan dengan menggunakan fitur ekstraksi, selanjutnya dilakukan eksperimen klasifikasi dengan menggunakan algoritma Random Forest. Pada penelitian ini kami menggunakan Python dan library yang terdapat pada sklearn, opencv, dan mahotas untuk mempermudah proses klasifikasi. Pada eksperimen ini dataset dibagi menjadi $80 \%$ data training dan $20 \%$ data testing. Hyperparameter yang digunakan yaitu menggunakan 100 n-estimator dan random seed 9. Hasil yang didapatkan pada eksperimen ini ditampilkan pada tabel 4.

Tabel 4. Hasil Akurasi Algoritma Random Forest

\begin{tabular}{lc}
\hline \multicolumn{1}{c}{ Fitur } & Akurasi \\
\hline Fitur Hu Moments & $42 \%$ \\
Fitur Haralick & $64 \%$ \\
Fitur Warna & $95 \%$ \\
Hu-Moment + Haralick + Warna & $96 \%$ \\
\hline
\end{tabular}

Berdasarkan tabel diatas dapat diketahui bahwa klasifikasi pada dataset penyakit daun tomat menggunakan Fitur $\mathrm{Hu}-$ Moment menghasilkan akurasi yaitu 42\%. Percobaan pada Fitur Haralick akurasi terdapat pada yaitu 64\%. Pada Fitur Warna akurasi tertinggi yaitu 95\% dan pada kombinasi ketiga fitur dihasilkan akurasi $96 \%$ dengan menggunakan algoritma Random Forest.

Setelah mengetahui bahwa algoritma Random Forest dengan kombinasi fitur yang menghasilkan akurasi terbaik, maka dalam penelitian ini menampilkan Confusion Matrix dari algoritma Random Forest dengan fitur yang telah dikombinasi. Confusion Matrix dari hasil penelitian ini dapat dilihat pada tabel 5.

Tabel 5. Confusion Matrik RF + Fitur Kombinasi

\begin{tabular}{|c|c|c|c|c|c|c|c|c|c|c|c|}
\hline \multirow{5}{*}{ 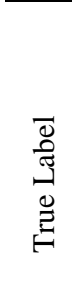 } & \multicolumn{11}{|c|}{ Prediksi } \\
\hline & & $\begin{array}{l}\text { Bacterial } \\
\text { spot }\end{array}$ & $\begin{array}{l}\text { Early } \\
\text { blight }\end{array}$ & $\begin{array}{l}\text { Late } \\
\text { blight }\end{array}$ & $\begin{array}{l}\text { Leaf } \\
\text { Mold }\end{array}$ & $\begin{array}{l}\text { Mosaic } \\
\text { virus }\end{array}$ & $\begin{array}{l}\text { Septoria } \\
\text { leaf spot }\end{array}$ & $\begin{array}{l}\text { Spider } \\
\text { mites }\end{array}$ & $\begin{array}{l}\text { Target } \\
\text { Spot }\end{array}$ & $\begin{array}{l}\text { Yellow } \\
\text { Leaf }\end{array}$ & healthy \\
\hline & $\begin{array}{l}\text { Bacterial } \\
\text { spot }\end{array}$ & 228 & 2 & 6 & 0 & 0 & 1 & 0 & 1 & 5 & 9 \\
\hline & $\begin{array}{l}\text { Early } \\
\text { blight }\end{array}$ & 11 & 238 & 4 & 0 & 0 & 1 & 1 & 1 & 2 & 0 \\
\hline & Late blight & 3 & 13 & 234 & 4 & 0 & 7 & 1 & 0 & 0 & 0 \\
\hline
\end{tabular}


JURNAL MEDIA INFORMATIKA BUDIDARMA

Volume 5, Nomor 1, Januari 2021, Page 186-193

ISSN 2614-5278 (media cetak), ISSN 2548-8368 (media online)

Available Online at https://ejurnal.stmik-budidarma.ac.id/index.php/mib DOI 10.30865/mib.v5i1.2624

\begin{tabular}{llllllllllll}
\hline Leaf Mold & 1 & 0 & 0 & 264 & 0 & 1 & 1 & 0 & 0 & 0 \\
$\begin{array}{l}\text { Mosaic } \\
\text { virus }\end{array}$ & 0 & 0 & 0 & 0 & 262 & 0 & 0 & 0 & 0 & 0 \\
$\begin{array}{l}\text { Septoria } \\
\text { leaf spot }\end{array}$ & 1 & 1 & 4 & 0 & 5 & 276 & 0 & 1 & 0 & 0 \\
$\begin{array}{l}\text { Spider } \\
\text { mites }\end{array}$ & 0 & 0 & 0 & 0 & 1 & 0 & 272 & 9 & 0 & 0 \\
$\begin{array}{l}\text { Target } \\
\text { Spot }\end{array}$ & 2 & 0 & 0 & 0 & 0 & 0 & 13 & 260 & 0 & 0 \\
$\quad \begin{array}{l}\text { Yellow } \\
\text { Leaf }\end{array}$ & 1 & 0 & 2 & 0 & 0 & 0 & 4 & 0 & 235 & 0 \\
\hline healthy & 0 & 0 & 3 & 0 & 0 & 0 & 1 & 1 & 0 & 256 \\
\hline
\end{tabular}

Pengenalan yang dihasilkan dengan algoritma Random Forest pada citra penyakit daun tomat dapat dikenali dengan baik pada kelas Leaf Mold, Mosaic virus, dan healthy dengan menghasilkan akurasi 99\% untuk masingmasing kelas tersebut. Hal tersebut terjadi karena pada kelas Leaf Mold terdapat 3 citra yang tidak terklasifikasikan sebagai penyakit Leaf Mold. 1 citra dikenali sebagai penyakit Bacterial spot, 1 citra dikenali sebagai penyakit Septoria leaf spot, dan 1 citra dikenali sebagai penyakit Spider mites. Sedangkan pada kelas Mosaic Virus 262 secara benar citra dikenali sebagai penyakit Mosaic Virus. Kemudian pada kelas healthy sebanyak 256 citra dapat dikenali dengan baik dan terdapat 5 citra tidak terklasifikasikan sebagai kelas healthy. 3 citra dikenali dengan penyakit Late blight, 1 citra dikenali sebagai penyakit Spider mites, dan 1 citra dikenali sebagai Target Spot.

Mengukur reabilitas dalam mengklasifikasikan citra penyakit daun tomat, penelitian ini menampilkan hasil perhitungan Kappa Statistik dalam grafik dibawah ini.

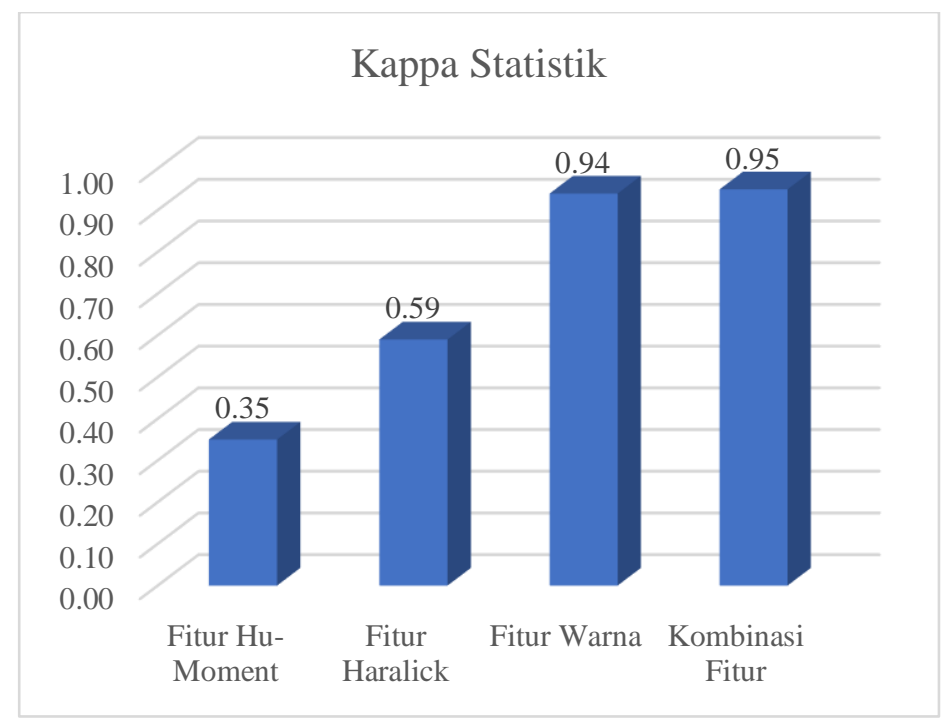

Gambar 3. Grafik Kappa Statistik

Pada algoritma Random Forest dengan Fitur Hu-Moment dari hasil perhitungan diperoleh kappa statistik 0.35. Pada Fitur Haralick diperoleh 0.59, kemudian dengan Fitur Warna diperoleh 0.94. Sedangkan hasil perhitungan kappa statistik pada kombinasi 3 fitur tersebut diperoleh 0.95. Nilai Kappa terbaik dalam penelitian ini terdapat pada Fitur Warna dan kombinasi 3 fitur karena nilai yang dihasilkan mendekati $\mathrm{K}=1$.

\section{KESIMPULAN}

Berdasarkan hasil pembahasan dalam menerapkan algoritma kalsifikasi dan berbagai ekstraksi fitur pada klasifikasi penyakit pada daun tomat, menunjukkan bahwa ketika data citra penyakit daun tomat proses ekstraksi hanya dilakukan dengan masing masing fitur menghasilkan akurasi yang baik terhadap algoritma klasifikasi. Pada Fitur Warna akurasi diperoleh yaitu 95\%, Fitur Haralick 64\%,dan fitur Hu-Moment 42\%. Kemudian kombinasi fitur dilakukan dengan menggabungkan proses ekstraksi pada fitur warna, fitur Hu-Moment, dan fitur haralick serta diklasifikasikan menggunakan Algoritma Random Forest menunjukkan peningkatan dengan akurasi sebesar 96\%. Hal ini dapat disimpulkan bahwa menggabungkan fitur tersebut dapat secara baik mengenali jenis penyakit pada citra daun tomat sehingga dapat dilakukan pengendalian secara tepat agar penyakit pada daun tomat tidak berkembang.

\section{REFERENCES}

[1] Felix, S. Faisal, T. F. M. Butarbutar, and P. Sirait, "Implementasi CNN dan SVM untuk Identifikasi Penyakit Tomat via 
JURNAL MEDIA INFORMATIKA BUDIDARMA

Volume 5, Nomor 1, Januari 2021, Page 186-193

ISSN 2614-5278 (media cetak), ISSN 2548-8368 (media online)

Available Online at https://ejurnal.stmik-budidarma.ac.id/index.php/mib

DOI 10.30865/mib.v5i1.2624

Daun," vol. 20, no. 2, pp. 117-134, 2019

[2] T. A. Salih, A. J. Ali, and M. N. Ahmed, "Deep Learning Convolution Neural Network to Detect and Classify Tomato Plant Leaf Diseases," Open Access Libr. J., vol. 07, no. 05, pp. 1-12, 2020, doi: 10.4236/oalib.1106296.

[3] J. Meliala, M. Hubeis, S. Jahroh, and A. Maulana, "Position of Farmers in Agriculture 4.0: Finding from Farmers Partner of Aggregator Online Vegetables Commodity in Indonesia," Arch. Agric. Environ. Sci., vol. 4, no. 3, pp. 300-306, 2019, doi: $10.26832 / 24566632.2019 .040307$.

[4] L. Klerkx and D. Rose, "Dealing with The Game-Changing Technologies of Agriculture 4.0: How Do We Manage Diversity and Responsibility In Food System Transition Pathways," Glob. Food Sec., vol. 24, no. December 2019, p. 100347, 2020, doi: 10.1016/j.gfs.2019.100347.

[5] H. Sabrol and K. Satish, "Tomato Plant Disease Classification in Digital Images using Classification Tree," Int. Conf. Commun. Signal Process. ICCSP 2016, pp. 1242-1246, 2016, doi: 10.1109/ICCSP.2016.7754351.

[6] J. Hang, D. Zhang, P. Chen, J. Zhang, and B. Wang, "Classification of Plant Leaf Diseases Based on Improved Convolutional Neural Network," Sensors (Switzerland), vol. 19, no. 19, pp. 1-14, 2019, doi: 10.3390/s19194161.

[7] E. Vamsidhar, P. J. Rani, and K. R. Babu, "Plant Disease Identification and Classification using Image Processing," Int. J. Eng. Adv. Technol., vol. 8, no. 3 Special Issue, pp. 442-446, 2019.

[8] G. Owomugisha, J. A. Quinn, E. Mwebaze, and J. Lwasa, "Automated Vision-Based Diagnosis of Banana Bacterial Wilt Disease and Black Sigatoka Disease," Int. Conf. use Mob. ICT Africa 2014, no. June, p. 5, 2014.

[9] P. R. Rothe and R. V. Kshirsagar, "Cotton Leaf Disease Identification using Pattern Recognition Techniques," 2015 Int. Conf. Pervasive Comput. Adv. Commun. Technol. Appl. Soc. ICPC 2015, 2015, doi: 10.1109/PERVASIVE.2015.7086983.

[10] J. Basavaiah and A. A. Anthony, "Tomato Leaf Disease Classification using Multiple Feature Extraction Techniques," Wirel. Pers. Commun., vol. 115, no. 1, pp. 633-651, 2020, doi: 10.1007/s11277-020-07590-x.

[11] "scikit-learn Machine Learning in Python," 2007. https://scikit-learn.org/.

[12] OpenCV, "Open Source Computer Vision," 2020. https://opencv.org/.

[13] L. P. Coelho, "Mahotas: Computer Vision in Python," 2008. https://mahotas.readthedocs.io.

[14] P. Liu, J. M. Guo, K. Chamnongthai, and H. Prasetyo, "Fusion of Color Histogram and LBP-Based Features for Texture Image Retrieval and Classification," Inf. Sci. (Ny)., vol. 390, pp. 95-111, 2017, doi: 10.1016/j.ins.2017.01.025.

[15] L. Rundo et al., Haralicu: GPU-Powered Haralick Feature Extraction on Medical Images Exploiting The Full Dynamics of Gray-Scale Levels, vol. 11657 LNCS. Springer International Publishing, 2019.

[16] Z. Deng and M. Cao, "Borehole Image Classification Using NSCT, Hu Moment Invariants and SVM Based APBCS System," 2019 2nd Int. Conf. Inf. Syst. Comput. Aided Educ. ICISCAE 2019, pp. 153-158, 2019, doi: 10.1109/ICISCAE48440.2019.221608.

[17] M. Govardhan and M. B. Veena, "Diagnosis of Tomato Plant Diseases using Random Forest," 2019 Glob. Conf. Adv. Technol. GCAT 2019, pp. 1-5, 2019, doi: 10.1109/GCAT47503.2019.8978431.

[18] V. Jackins, S. Vimal, M. Kaliappan, and M. Y. Lee, "AI-Based Smart Prediction of Clinical Disease Using Random Forest Classifier and Naive Bayes,” J. Supercomput., no. 0123456789, 2020, doi: 10.1007/s11227-020-03481-x.

[19] T. Purwa, "Perbandingan Metode Regresi Logistik dan Random Forest untuk Klasifikasi Data Imbalanced (Studi Kasus Klasifikasi Rumah Tangga Miskin di Kabupaten Karangasem, Bali Tahun 2017),” J. Mat. Stat. dan Komputasi, vol. 16, no. 1, p. 58, 2019, doi: 10.20956/jmsk.v16i1.6494 